\title{
THE IRRELEVANT MYSTERY, THE INVOLUNTARY DETECTIVE, THE MELTING CLUE: NOTES ON LA PISTA DE HIELO, A NEOPOLICIAL By Roberto Bolaño \\ EL MISTERIO IRRELEVANTE, EL DETECTIVE INVOLUNTARIO, LA PISTA DE HIELO: ALGUNAS NOTAS EN TORNO A UN NEOPOLICIAL DE ROBERTO BOLAÑO Julia González-Calderón \\ University of California Los Angeles - CA, Estados Unidos
}

\begin{abstract}
This article analyzes La pista de hielo (The Skating Rink, 1993), the third novel by Roberto Bolańo, as an exponent of the Ibero-American neopolicial, focusing on how two of the main dramatic elements of the detective tale, the enigma and the detective figure, are decentralized through a series of narrative mechanisms that eventually dismantle traditional genre conventions. Furthermore, we will link La pista de hielo and its narrative key elements with the rest of the novelistic of the Chilean author, as well as with the main exponents of the neopolicial, such as Paco Ignacio Taibo II, Leonardo Padura or Ramón Díaz Eterovic.
\end{abstract}

Keywords: Bolaño, Latin American fiction, detective fiction, neopolicial.

\section{Resumo}

Este artigo analisa o terceiro romance de Roberto Bolaño, La pista de hielo (1993), desde uma leitura do texto como exponente do neopolicial iberoamericano tal como o caracteriza a crítica e focalizando-se em como dois dos componentes dramáticos da narração policial clássica, o enigma e o detetive, são deslocados por meio de um conjunto de mecanismos narrativos que desarticulam as convençóes tradicionais do género. Ademais, vincularemos La pista de hielo e as suas chaves narrativas com o resto da novelística do autor chileno e com os principais exponentes do neopolicial,

\section{Resumen}

Este trabajo analiza la tercera novela de Roberto Bolaño, La pista de hielo (1993), desde una lectura del texto como exponente del neopolicial iberoamericano tal y como lo ha venido caracterizando la crítica y estudia cómo dos de los elementos dramáticos centrales de la narración policial clásica, el enigma y el detective, son desplazados mediante una serie de mecanismos narrativos que desarticulan las convenciones tradicionales del género. Además, vincularemos La pista de hielo y sus claves narrativas con el resto de la novelística del autor chileno y con los principales exponentes del neopolicial, 
como são Paco Ignacio Taibo II, Leonardo Padura ou Ramón Díaz Eterovic.

Palavras-chave: Bolaño, neopolicial, romance policial, romance IberoAmericano. como son Paco Ignacio Taibo II, Leonardo Padura o Ramón Díaz Eterovic.

Palabras claves: Bolańo, narrativa hispanoamericana, neopolicial, policial.

Roberto Bolaño introduced the techniques of detective fiction in most or all of his works in a highly original way. We find detective-themed plots in the robberies of Consejos de un discipulo de Joyce a un fanático de Morrison, written along with Antoni García Porta; in the tortuous inquests that the main character of Monsieur Pain unsuccessfully carries out around an agonizing César Vallejo in Paris; in the main character and the detective Abel Romero chasing fascist Carlos Wider in Estrella distante; in the search for Cesárea Tinajero performed by Arturo Belano and Ulises Lima, as well as the search that somebody does for them years later in Los detectives salvajes; and in the again literary inquiry around the mysterious German author Archimboldi in 2666.

The aim of this article is to explore the third novel by the Chilean autor, La pista de hielo (The Skating Rink, 1993), reading it as an exponent of the Ibero-American neopolicial, as described by Leonardo Padura in his classic interview with Juan Armando Epple in Hispamérica (1995). I would, thus, overcome the lack of attention that this novel has been receiving so far. La pista de hielo is more accessible than the colossal 2666 and Los detectives salvajes, and less perfect than Estrella distante or Nocturno de Chile, but it is aesthetically and thematically linked with the rest of his novels, as Bolaño introduced the codes of detective fiction in all his works. Specifically, I am going to focus my analysis of the novel on the construction of an irrelevant mystery as the axis of a plot that denies any worldview based on causality, and on the figure of the detective in the novel. I am also going to connect La pista de hielo with the rest of the Latinoamerican neopolicial production: novels by Leonardo Padura, Paco Ignacio Taibo II, and Ramón Díaz Eterovic, mostly.

Although it was Leonardo Padura who popularized the expression "neopolicial Ibero-Americano" for the subgenre born in Latin America during the seventies, it was actually Paco Ignacio Taibo II who coined the term. In addition, Taibo II is regarded as the "father" of the subgenre with his novel Días de combate (1976) and as a great promoter of Hispanic detective fiction in the international literary circles. In general, critics have considered the following as the main characteristics of the neopolicial fiction: the decrease of the enigma's importance as an essential dramatic element, the detective as a defeated hero in an atmosphere of disappointment and failure, the relevance 
of the urban space, the social critique, and the self-parodic awareness of the genre, as novels often include intertextual references and literary mysteries, or make a mixture between the figure of the detective and that of the writer or the critic'.

La pista de hielo was first published in 1993 after being awarded in Spain with the Premio de Novela Ciudad de Alcalá. Its distribution, as usual in these cases, was quite limited and the novel soon disappeared from the literary scene without practically having been noticed. However, Anagrama republished it in 2009, when it was more than evident that any book signed by Bolaño assured good sales and Jorge Herralde and the heirs of the author agreed on the publication of a few novels, unpublished until the date. Among those novels are, apart from La pista de hielo: El Tercer Reich, Los sinsabores del verdadero policía, El espiritu de la ciencia ficción, and Sepulcros de vaqueros.

The subjects of La pista de hielo are, paraphrasing Bolaño, beauty and its ephemeral nature: "En La pista de hielo (1993) hablo de la belleza, que dura poco y cuyo final suele ser desastroso" (BOLAÑO, 2012, p. 19). We cannot obviate the fact that this same disastrous end that Bolaño credits to beauty connects directly with his ideas about defeat, a subject with a relevant presence not only in his fiction, but also in neopolicial in general:

Yo soy de los que creen que el ser humano está condenado de antemano a la derrota, a la derrota sin apelaciones, pero que hay que salir y dar la pelea y darla, además, de la mejor forma posible, de cara y limpiamente, sin pedir cuartel (porque además no te lo darán), e intentar caer como un valiente, y eso es nuestra victoria. (HERRALDE, 2007, p. 101)²

Defeat is a substantial part of life for Bolaño and, therefore, it is also present in the literary creation process:

En mi cocina literaria ideal vive un guerrero, al que algunas voces (voces sin cuerpo ni sombra) llaman escritor. Este guerrero está siempre luchando. Sabe que al final, haga lo que haga, será derrotado. Sin embargo recorre la cocina literaria, que es de cemento, y se enfrenta a su oponente sin pedir cuartel. (BOLAÑO, 2012, p. 323)

1 To read more about neopolicial features, see Epple (1995), García Talaván (2014), Giardinelli (1996), Martín Escribá and Sánchez Zapatero (2007), Noguerol Jiménez (2006), Padura Fuentes (1999), and Trelles Paz (2006). To read more on literary neopolicial, see Pellicer (2007).

2 Bolaño expressed himself with similar words, although epigramatically, when asked by Mónica Maristain for Playboy if "el mundo tiene remedio": "El mundo está vivo y nada vivo tiene remedio y esa es nuestra suerte" (BOLAÑO, 2012, p. 342). 
He expressed himself in the same terms when asked about 2666: "Mire, probablemente mi novela será un fracaso. No es nada nuevo fracasar" (STOLZMANN, 2012, p. 376). This awareness of failure connects directly with the neopolicial written in the rest of the continent. The titles of many of these novels already evidence the importance of failure, as we can notice with Manual de perdedores 1 and 2 (1985 and 1987), by Juan Santurain; No habrá final feliz (1989), by Taibo II; Perder es cuestión de método (1997), by Santiago Gamboa, or Ni el tiro del final (1981), by Pablo Feinmann. We see here the expression of a feeling of defeat of those who, at least, can be proud of knowing that they gave everything they could before falling. Taibo II said about his fictional creatures in an interview: "mis personajes nunca se mueren del pesimismo, sino que después de la derrota retornan. $\mathrm{Y}$ creo que la clave es esa. Yo escribo historias de derrotados que no se rinden" (NICHOLS, 1998, p. 221).

Beauty is, like ice, damned to expiration, and this idea is expressed already in the novel's title, for "pista de hielo" might mean the frozen surface purposed to the practice of ice skating, but it is also an oxymoron, as pista also refers to the evidence found by detectives during their investigation. It is a term linked to the concepts of pragmatism, logic, and reasoning. On the contrary, ice symbolizes everything that is at risk of disappearing, of everything that is not consistent. Thus, the novel can be labelled from its title as an exponent of neopolicial fiction. It is interesting to note that this is not Bolaño's only title using this technique: Los detectives salvajes (The Savage Detectives) also contains an oxymoron, for a detective is essentially a logic entity, while a savage being is primitive and linked to the idea of irrationality (MORA, 2011, p. 173).

The story is set in Z, a small touristic town on the Spanish Costa Brava, at the beginning of the eighties. There are three narrators who conform a sort of "tríada confesional" (PINO, 2006, s/p): Remo Morán, Gaspar Heredia, and Enric Rosquelles. Each of them narrates a chapter in a successive order that is never altered, though none of them is the murderer nor the detective, which is a renovation of the narrative technique of presenting the speech of the crime's witnesses. This technique was already implemented in The Moonstone by Wilkie Collins, considered to be the first detective novel ever (SÁNCHEZ VELASCO, 2010).

Remo Morán is a frustrated writer and a Chilean entrepreneur who owns, among other businesses, a campsite. Mexican Gaspar Heredia, who was an intimate friend of Morán's years ago in Mexico City, arrives in town to work at the campsite as a safety guard. There, Heredia meets Carmen and Caridad, two homeless women who live at the campsite.

Enric Rosquelles is a Catalan psychologist in charge of the Personal Services of the City Council. He meets Nuria, a young figure skater who, 
due to her age (she has already turned nineteen), has been disqualified for the next Olympic Games. Rosquelles falls madly in love with Nuria and decides to use public money to build, only for her, an ice rink inside an abandoned palace in the town's outskirts, the Bevingut Palace. Carmen discovers the rink by chance and blackmails Enric: if he does not provide her and Caridad with housing, she will make the scam public. And only at this point does the corpse appear: Gaspar, and Remo after him, find Carmen stabbed to death on the ice rink.

The finding of the corpse involves the finding of the financial offence, too, and Enric Rosquelles will end up spending a brief time in prison. While Morán continues his quiet life in Z, Nuria moves to Barcelona, where Gaspar and Caridad, finally together, also move.

One of the main features of the Ibero-American neopolicial is the decreasing importance of the enigma as an essential dramatic element. The action does not move around the crime, but, rather, around its circumstances. One of the characters of La vida misma by Taibo II confirms this idea: "Es una novela de crímenes muy jodidos, pero lo importante no son los crímenes, sino (como en toda novela policíaca mexicana) el contexto" (TAIBO II, 1987, p. 170).

Thus, crimes in neopolicial often remain unresolved, or they might be resolved but the reader cannot be totally sure that the one identified as the criminal is, indeed, the criminal, or perhaps an innocent person is punished, among many other possibilities that prove that the world we inhabit lacks any kind of certitudes. Unresolved investigations and open endings are, therefore, very common in these stories that need a very active reader to put together the pieces of the puzzle and ask the correct questions. In La ciudad está triste, for instance, Heredia finds out what happened to the young girl missing and he lets her sister know that "[l]a policía está al tanto de todo lo ocurrido, pero dudo que muevan un dedo" (DÍAZ ETEROVIC, 2000, p. 66). Indeed, the police are willing to ignore that some government hitmen killed a young, innocent girl, so Heredia decides to take the law into his own hands and, far from being an orthodox detective, executes all those involved in her death. His friend Solís tries to stop him before he kills the ultimate responsible of the murder, saying that "no es necesario". The detective answers: "¿Me aseguras que afuera lo van a juzgar; que no va a existir un juez maraco que lo libere?” (DÍAZ ETEROVIC, 2000, p. 74). As Solís reacts to his question with silence, Heredia pulls the trigger.

In neopolicial fiction, justice, which "tiene doble venda sobre los ojos" (DÍAZ ETEROVIC, 2000, p. 66), reveals itself as a chimerical and unreachable entity, as, generally, when the detective makes progress in his or her investigation he or she realizes that it is impossible to reestablish any 
harmony by catching the culprit of any given crime, because crime roots expand themselves to the deepest waters of a corrupted system: "los detectives concluyen que el enemigo es el sistema y que la búsqueda del orden y de la justicia es un acto fallido" (VARAS, 2006, s/p). Finding out the criminal's identity is not the problem, but rather assuming that these remain above the law. Heredia mocks the naive idealism of traditional detective novels: "Las pistas que revelan al culpable en la última página son para las novelas; en la realidad los asesinos ostentan sus culpas con luces de neón. Se conocen sus nombres y apellidos, pero nadie hace nada por juzgarlos" (DÍAZ ETEROVIC 2000 , p. 67$)^{3}$.

Guilt is often diluted to acquire a collective shape: it is impossible to blame only one person or a certain number of individuals, for these are simply countless. Thus, in the Belascoarán Shayne series, the detective ends up necessarily concluding that the guilty parties are, ultimately, the system and the State, sustaining each other. He puts it down in these terms in the third novel of the saga, Algunas nubes:

Sabía que cuando llegara al final, si llegaba, la iba a encontrar con una pared que impediría la justicia. Encontraría un muro de situaciones creadas, compromisos, escritorios, fuerza, costumbres, complicidades que abarcaban desde la última esquina del mundo del hampa hasta los cielos del poder, trenzados sutilmente a lo largo del tiempo. (TAIBO II, 2010, p. 332)

\section{And his impression is reassured in the following novel, No habrá final feliz:}

No bastaba con eso de "los malos", tenía que darles nombres, caras, situaciones. Nebulosamente, Héctor, que nunca se había dado de hocico contra el poder, percibía al Estado como el gran castillo de la bruja de Blancanieves ${ }^{4}$, del que salían no solo los Halcones, sino también los diplomas de ingeniero y la programación de Televisa. No había matices. Todo era una máquina infernal de la que había que alejarse. Eso, o personajes concretos con los que entablar duelos épicos y precisos. Pasaba de una visión a otra: del match

3 Castellanos Moya denounces the same insufferable impunity in Insensatez: survivors of Mayan genocide and the rest of Guatemalan society know very well who the responsibles are and, however, silence rules the country.

4 It would be perhaps interesting to connect No habrá final feliz with the Spanish protest novel El padre de Blancanieves, by Belén Gopegui (2007), which formulates an allegory between Spanish reality at the end of the twentieth century and the children's story of Snow White: Spain is Snow White's castle, and the princess is the citizenry, abused by privileged sectors of society (corporations, banks, great employers), or the cruel stepmother. In this bleak picture, where is Snow White's father (the government) to defend his daughter and establish harmony and justice in his house? In savage neoliberalism, we cannot expect our dads to come to protect as, as they are absent and they have left their daughters at the mercy of the cruel stepmothers. 
simplificado Bakunin vs. el Estado, al match simplificado Sherlock Holmes vs. Moriarty. En medio nada había, quizá ahí estaba la causa del juego con los "malos" ambiguos, porque en ellos se fundían las dos versiones. (TAIBO II, 2010, p. 461)

Novels by Díaz Eterovic also point to power as the phantasmagoric ultimate responsible of evil: "Quienes dirigían la ciudad se reservaban el juego sucio entre las manos y no se necesitaba mucha imaginación para saber de dónde provenía la violencia” (DÍAZ ETEROVIC, 2000, p. 37). Indeed, detective Heredia abandons Law School" when he realizes that "la justicia se movía por otra parte, amparada por la complicidad del dinero y el silencio" (DÍAZ ETEROVIC, 2000, p. 10).

In La pista de hielo crime does not take place until we have read almost three quarters of the novel: if it has 200 pages, the corpse does not appear until page 146, when Remo Morán finds it by chance. The enigma is not at all the main dramatic element, nor the issue that makes the plot move. Rather, the plot moves towards the murder, but not from it, as the relevant information is not who killed Carmen, but all the circumstances that surrounded her murder until it took place: "lo que importa es otra cosa, no el cuchillo o el asesinato, sino la vida marginal y castigada de la mayoría de los personajes" (PINTO, 2002, p. 64).

Franken Kurzen (2013) differentiates two different typologies of crime in current Chilean detective novel, the crime of passion and the institutional crime, and classifies La pista de hielo among those that revolve around a crime of passion and, with that, explore the nature of human relationships and low passions, as opposed to those that explore the moral corruption of the system. However, it is clear to me that Bolaño's novel exceeds this dichotomous division, as we actually face two different crimes in his novel: Carmen's murder is the crime of passion on which the narrators force the reader to focus, but there is another crime in the novel: the embezzlement committed by Rosquelles. As the narrators pay little attention to this secondary crime, the reader does the same, although it has a great media coverage in fictional Z. Bolaño plays around both types of crime, using them to build a ferocious social critique, because in the novel the media's attention, contrary to the reader's, focuses on the corruption, leaving aside the murder case.

\footnotetext{
$5 \mathrm{He}$ is not the only neopolicial detective who has abandoned his career: Mario Conde leaves also college to become a policeman and, although Héctor Belascorán works for a few years as an engineer, he also quits to become an independent detective (expression that he prefers to "private detective", which has a capitalist connotation). Mediocrity of ordinary media class life means the worst possible failure for these vocational investigators. Thus, Heredia recognizes that he likes his job: "Si no fuera así, habría puesto llave a mi oficina, regalado la pistola calibre cuarenta y cinco, y desde hace unos ańos vegetaría en un empleo público, esperando los fines de semana para salir a pasear en un auto cancelado con interminables cuotas mensuales" (DÍAZ ETEROVIC, 2000, p. 10).
} 
The murder remains eventually unresolved and justice soon files the case. However, we get to know who the murderer is in the last moment: the so called Recluta, a homeless man who was Carmen's lover. We get to this conclusion not through an investigation based on logical-deductive thought and scientific methodology, but by mere accident: Recluta suddenly confesses to Morán. This way, Bolaño highlights the fact that we inhabit a world ruled by principles that follow no order but the order of chaos, "el azar o ese monstruo aún más salvaje que es la casualidad" (BOLAÑO, 2009, p. 41): "desde el punto de vista epistemológico, Bolaño niega la posibilidad de encontrar la verdad o un sentido. [...] queda la sensación de que jamás se podrá conocer una sola y única verdad sobre los hechos acontecidos" (FRANKEN KURZEN, 2013, p. 248).

Bolaño thinks of the most important events of his own life under the light of this same chaotic and delirious cosmovision. For instance, when asked in an interview why he had ended up living in Spain, his answer was "por la casualidad, el azar", and when asked then if he would ever go back to Chile he replied that, if he did, his return would be "también por azar" (HERNÁNDEZ Y PUIG, 2008, p. 476) ${ }^{6}$.

The scene in which Recluta spontaneously confesses to Morán, in the lonely atmosphere of the beach with a threatening storm in the horizon, reflects the insignificance of the conversation for the world and questions the possibility of an authentic human communication:

Yo la maté, patrón, me dijo el Recluta, mientras las olas se acercaban a intervalos regulares, cada vez un poco más, a sus rodillas. La playa estaba vacía; en el horizonte, sobre el mar, se revolvían nubes negras y gordas. Una hora más, pensé, y la primera tormenta de otońo, como un portaaviones, pasará sobre Z y nadie nos oirá. (p. 195)

In the novel, Bolaño uses the procedure of "la decepción sistemática de las expectativas del lector de género" (ROSSO, 2002, p. 135). The reader will immediately notice a threatening atmosphere surrounding the young and beautiful skater, but nothing will happen to her. Because Rosquelles had been blackmailed by Carmen, we might assume that he is the murderer, but he can prove that he was somewhere else at the time of the crime. In the same way, Bolaño contradicts Chekhov's gun principle, which dictates that if a

6 The protagonist of Bolaño's second novel, Monsieur Pain, whose lungs were almost destroyed by World War I gases but was finally able to survive, talks in the same way about coincidence as the world's moving force: "A los veintiún años me quemaron los dos pulmones en Verdún. Los médicos que me recogieron no supieron nunca cómo logré mantenerme con vida. Gracias a la voluntad, fue mi respuesta. Como si la voluntad tuviera algo que ver con la vida y sobre todo con la muerte. Ahora sé que fue gracias a la casualidad. Y saberlo no es ningún consuelo" (Bolaño 1999: 84). 
weapon appears in the first act of a drama someone must pull the trigger in the third. The reader's attention is drawn again and again to Caridad, who carries a big knife with her at all moments and is, furthermore, mentally ill. Eventually, however, this feared knife will not harm anybody and Caridad is ultimately nothing but another marginal victim of the postmodern city. She is regularly at Benvingut Palace because it is a good haven and probably carries a knife because she is scared of being attacked, which forces the reader to wonder about her past: what circumstances have taken this young woman to go everywhere with a knife?

While narrators insist on the latent danger of Caridad, they do not say a word about Recluta. No clue, no evidence takes the reader to suppose or imagine that he is the murderer. Only Álex, Remo's employee and best friend, irrationally senses something and kicks him out of the hotel in a rude way:

Cuando la fiesta terminó le pregunté a Álex por qué obró tan contundentemente contra un pobre mendigo que nada nos había hecho. No lo sabe, instintivamente desconfía del Recluta. Prefiere no verlo rondando por el hotel. Tampoco quiere que yo lo vea. ¿Qué es lo que más te disgusta de él?, pregunté. Los ojos, dijo Álex, son ojos de loco. (p. 180)

The parodic use of the cliffhanger ending in every chapter of the novel is another resource of this kind. All chapters close abruptly and with ellipsis after announcing or insinuating the existence of an enigma. They remind us of Agatha Christie's chapter's endings, that sound so theatrical and artificial to nowadays readers ${ }^{7}$. Here are the ends of the three first chapters in La pista de hielo:

¡De la calle Bucareli, en México, al asesinato!, pensarán... El propósito de este relato es intentar persuadirlos de lo contrario... (p. 10)

Al dejar atrás la Estación de Francia pensé que nunca más volvería a vivir en Barcelona. ¡Atrás y fuera de mí! ¡Sin dolor ni amargura! A la altura de Mataró empecé a olvidar todos los rostros... Pero, claro, es un decir, nada se olvida... (p. 12)

Dios mío, cuántas cosas tuve que hacer, cuánto que tragar y digerir a solas con mi alma. Hasta que conocí a Nuria y cayó en mis manos el proyecto del Palacio Benvingut... (p. 15)

7 Thus, third chapter of And Then There Were None closes with a character saying: "Oh, yes. I've no doubt in my own mind that we have been invited here by a madman, probably a dangerous homicidal lunatic" (Chrsitie 2011: 31). Fourth chapter ends with a surprising death: "He picked up his drink and drank it off at a gulp. Too quickly, perhaps. He choked, choked badly. His face contorted, turned purple. He gasped for breath, then slid down off his chair, the glass falling from his hand" (Christie 2011: 37). 
Raymond Chandler (2016) claimed that the criminal must always be punished in a good hard-boiled novel, even if the punishment does not come through traditional justice ${ }^{8}$. This is the case of many neopolicial novels. For instance, despite the atmosphere of disenchantment and failure surrounding him, detective Mario Conde always finds out who the murderer is and gets the necessary evidence -usually including a confession-to have them prosecuted in the seasons tetralogy by Leonardo Padura. La ciudad está triste by Díaz Eterovic offers a different version of a criminal being punished, as the detective, who knows too well that authorities will not do anything about it, takes justice on his own hands. There is no punishment at all, however, in Bolaño's novel: Remo Morán does not do anything after discovering the murderer's identity. He does not go to the police nor takes revenge, nor tells anybody. Punishment made sense in the hard-boiled fiction, when it meant the restoration of the harmony existing before the crime, but in Bolaño's universe there is simply no harmony to be restored. The universe was a chaos before the crime and will continue to be so after it, and punishment is as meaningless as any other desperate and futile action attempting to order reality. In this sense, Bolaño's novel connects more with Taibo II's neopolicial: No habra final feliz closes not only with the impunity of the criminals, but with the detective's death.

Recluta does not either receive a "divine" punishment: nothing happens to him, he does not die or suffers an accident. Everything suggests that he just continues with his life: how can those who are somehow already being punished be punished? Recluta is a marginal individual who sleeps on the street and probably suffers from some mental illness. Throughout the entire text Bolaño plays with the dual identification of characters both as victims and aggressors at the same time, as they are pushed to the limits by marginal and extreme lifestyles: Carmen is murdered, but she was also blackmailing; Caridad is homeless and mentally ill, but precisely because of that she is also dangerous and threatens to stab those who intimidate her; Recluta is also a homeless man and he suffered Carmen's rejection to strengthen their relationship, but he is a murderer; Nuria takes advantage of Enric's love so that she can train on the illegal ice rink, but she will have to say goodbye forever to competition after the embezzlement scandal; Remo lives overwhelmed by loneliness, but denies his friendship to Heredia; Enric abuses his power to build the rink and is xenophobic, but eventually is abandoned by Nuria, loses his job and credibility and goes to jail. All of them are guilty or all of them are innocent, which Coello Gutiérrez has considered a critique that is ethical rather than political (2013, p. 80).

8 "It [detective novel] must punish the criminal in one way or another, not necessarily by operation of the law $[\ldots]$. If the detective fails to resolve the consequences of the crime, the story is an unresolved chord and leaves irritation behind it" (CHANDLER, 1976, p. 35). 
As with the enigma, the detective's role in neopolicial fiction is also decentralized and he/she is often neither the narrator nor the character on which the attention is focused. The reader can access the story not through the eyes of the victim or the murderer, as practiced in English and North American hard-boiled novel, but throughout the eyes of those who have witnessed the events and who frequently belong to the marginal areas of the big city.

Neopolicial fiction refuses to create great heroes and choses protagonists who are "gente frustrada, jodida y [que] no tienen nada de héroes" (Epple 1995, p. 60). The awareness of failure as the inevitable fate of all investigations and, by extension, of all humans' goals is, probably, one the most significant features of this fiction, product of a group of writers, all of them leftists, who have been brought together by the experience of having believed in a social change that would finally never materialize (GARCÍA TALAVÁN, 2011, p. 51).

The detective is not at all the central character in La pista de hielo, as it is neither the mystery in this plot that dismantles and disarticulates the elements considered, until very recently, as essential to build a detective tale. Actually, the only detective, strictly speaking, who appears is the local policeman who arrests Rosquelles for spending public money and as a murder suspect. As far as the murder is concerned, Rosquelles can easily prove his innocence and, from that point on, the police's attention, as well as Z's, focuses on the defalcation: everyone seems to ignore the fact that a human being has been violently killed.

Morán is the character who is closer to the detective's figure, although he is a sort of a savage detective, or something that I prefer to call the involuntary detective. An involuntary detective is a character that frequently appears in neopolicial fiction, full of accidental detectives who end up investigating a case dragged by an urgent ethical sense. Why risking their lives investigating matters that do not directly concern them? Involuntary detective José Giustozzi tries to explain it in Qué solos se quedan los muertos:

me pregunté por qué lo haría. ¿¿Por qué seguir, si Carmen estaba muerta y yo sabía que cuando se muere quien amas, todo el mundo queda vacío y nada importa? No tenía claro qué quería saber, o encontrar, pero me parecía importante entender el por qué [sic] de la muerte de Carmen [...].

No lo tenía claro, pero quizás seguí adelante simple y sencillamente porque hay cosas que no se deben abandonar; hay momentos en los que un hombre hace ciertas cosas por la única razón de que debe hacerlas. En esos momentos no se sabe qué es lo mejor ni qué lo peor, qué es el bien ni qué es el mal. Uno solo siente que debe seguir, y sigue... (GIARDINELLI, 1986, p. 127-128) 
The circumstances usually push them to go forward and, after knowing about the mystery, which is commonly a morally provoking issue, there is no way back. Morán himself confesses that he feels appealed by the profession: "A veces por las mañanas, cuando desayuno solo, pienso que me hubiera encantado ser detective. Creo que no soy mal observador y tengo capacidad deductiva, además de ser un aficionado a la novela policíaca. Si eso sirve de algo..." (p. 117-118).

Involuntary detectives are very common in Bolaño's fiction. I am talking about the four professors who search for Archimboldi in 2666; the aspiring poets and drug dealers who try to locate Cesárea Tinajero in Los detectives salvajes; the mesmerist acupuncturist who finds himself trapped in the indecipherable nets surrounding César Vallejo's death in Monsieur Pain; Arturo Belano (doubly savage detective) chasing fascist Ruiz Tagle/Wieder in Estrella distante; and, of course, Morán, the Chilean expat and entrepreneur who broods over the murder in La pista de hielo.

Bolaño is not, of course, the only author who has used this kind of character, which we can find also in the journalist José Giustozzi in Qué solos se quedan los muertos by Argentinian Mempo Giardinelly; young activist Emilia in Que me maten si by Guatemalan Rodrigo Rey Rosa; anthropologist Yolanda in El corazón del silencio by the Chilean and Costa Rican Tatiana Lobo; journalist Rita Mena in Baile con serpientes by Salvadorean Horacio Castellanos Moya; or the journalist Pepe Pindonga in Donde no estén ustedes, also by Castellanos Moya. The great number of journalists forced to improvise as detectives seems to indicate that authors are demanding the press to carry out the job that the police authorities of a deeply corrupted Latin America are not doing?

The word detective appears only twice in the text: in the quote that we have already mentioned and, again in the same chapter, in a very negative context that demonstrates the justified lack of trust in any kind of institutionalized justice: Morán remembers the first time he ever saw a corpse, while he was imprisoned in Chile after Pinochet's coup d'état and two policemen beat up a prisoner until he died.

The reader is ultimately denied the absolute certitude of knowing who the murderer is, for the Recluta has confessed, but how do we know if he is

\footnotetext{
9 And their wishes, at least in the case of El Salvador, are becoming true with front-line newspapers such as ElFaro.net, first Latin American online newspaper, founded by Salvadorean Carlos Dada and Jorge Simón in 1998 under the principles of a rigorous, independent, and high-level journalism. Given their lack of economic resources, they decided to create an online medium, so that it would be accessible for everyone, everywhere and for free. After almost two decades of work, El Faro represents the vanguard of current Latin American journalism and has recently been awarded with the prestigious Premio Latinoamericano de Periodismo de Investigación 2016-17.
} 
telling the truth? This poor madman's words are all the evidence we are given. Thus, in La pista de hielo we face a fragmented, irrational reality in which there are no answers or assurances and in which characters are in despair, lost in a bewildering universe they do not understand. The presentation of facts and events in a hectic and disperse way forces, on the one hand, the reader into an equally hectic and disperse reality, and makes an active reading necessary. By actively reading, as promulgated by Borges, the reader puts together little by little the disjointed puzzle pieces until he or she gets a clear picture of the narrated events. The reader is, ultimately, the true detective in this plot, as the text "transforma al lector de Bolaño en un sujeto siempre a la busca de algo esquivo e indescifrable: un detective en busca de las pistas de un crimen que nunca se cometió" (ROSSO, 2002, p. 140). This kind of reader is present, actually, "en todos los textos de Bolaño, inclusive en sus cuentos. En todos ellos, prescindiendo de los rasgos clínicos, nos encontramos con lectores al borde de la paranoia, lectores que buscan sentidos secretos en las cosas del mundo" (ROSSO, 2002, p. 142) ${ }^{10}$.

However, the typical paranoid reader of detective genre will crash here against a chaotic nonsense when trying to put together the pieces of a puzzle whose solution eventually lacks actual interest. It will be impossible, no matter how much we speculate about it, to know if the murderer is, indeed, Recluta, or another person. But... does that really matter? Because: "Como se ve, el lector que propone Bolaño es un lector conjetural, un lector que propone hipótesis para ciertos hechos oscuros en la trama cuya resolución carece de importancia" (ROSSO, 2002, p. 139).

Paula Aguilar contrasts the iceberg image used by Hemingway to talk about his own poetics (Plimpton 1958) to the ice rink image. In the North American writer's stories, fiction events rely upon layers and layers of hidden material, invisible for the reader's eyes but pulsing in the text's silences and voids, which the reader needs to fill in. On the contrary, the flat surface of La pista de hielo "solo permite el deslizamiento a la deriva o la vuelta en círculos que no conduce a nada, porque la superficie resbaladiza del policial no permite desentrañar lo oculto" (AGUILAR, 2013, p. 191). Therefore, in the story "nada hay que emerja y otorgue completamente sentido a lo que apenas se muestra. Porque los indicios del relato no se constituyen como vías de acceso a lo oculto y soterrado sino por el contrario se quedan en la superficie, se deslizan sobre la pista de hielo" (AGUILAR, 2013, p. 180).

\footnotetext{
10 Thus, Graham Greenwood, a North American collector of literary oddities and theorist on the topic of evil in Estrella distante, defends a certain kind of reading: "Para luchar contra el mal recomendaba el aprendizaje de la lectura, una lectura que comprendía los números, los colores, las señales y la disposición de los objetos minúsculos, los programas televisivos nocturnos o matutinos, las películas olvidadas" (BOLAÑO, 2013, p. 111).
} 
The analysis of La pista de hielo reveals how Bolaño had the same stylistic and thematic concerns during his entire career, as all his fiction works revolve around the same issues: detective genre deconstruction through original, alternative plots that take a distance from classical genre codes, involuntary detectives, irrelevant crimes... La pista de hielo, as almost all his novels, can be without hesitation listed as a neopolicial exponent. Its pessimistic vision upon the world, that assumes that all effort is damned to failure, connects with the cosmovision shared by the rest of the neopolicial authors. By decentralizing murder as the central axis of the novel's plot, Bolaño forces the reader to focus on all the material and human circumstances that have brought us to the crime, building a ferocious social critique. In the chaotic and disorganized universe of the novel, the crime's resolution is, as the crime itself, irrelevant, as it does not ensure the return to some inexistent previous harmony. Thus, Bolaño forces the reader to skate on the novel, escorting the characters, who are victims and aggressors at the same time, in their comings and goings through Z, and forces Morán, involuntary detective, to find out again and again the impossibility of grabbing any certitudes in a universe in which all axioms are destined to melt like ice.

References

AGUILAR, Paula. Libros de arena, desiertos de horror: la narrativa de Roberto Bolaño. Doctoral dissertation. National University of La Plata: La Plata, 2013.

BOLAÑO, Roberto. Estrella distante. Barcelona: Anagrama, 2013.

BOLAÑO, Roberto. Entre paréntesis. Barcelona: Anagrama, 2012.

BOLAÑO, Roberto. La pista de hielo, Barcelona: Anagrama, 2009.

BOLAÑO, Roberto. 2666. Barcelona: Anagrama, 2009.

BOLAÑO, Roberto. Los detectives salvajes. Barcelona: Anagrama, 2007.

BOLAÑO, Roberto. Monsieur Pain. Barcelona: Anagrama, 1999.

BOLAÑO, Roberto and PORTA, Antoni G. Consejos de un discípulo de Morrison a un fanático de Joyce. Diario de bar. Barcelona: Acantilado, 2006.

CASTELLANOS MOYA, Horacio. Baile con serpientes. Barcelona: Tusquets, 2012.

CASTELLANOS MOYA, Horacio. Insensatez. Barcelona: Tusquets, 2005. 
CASTELLANOS MOYA, Horacio. Donde no estén ustedes. Barcelona: Tusquets, 2003.

CHANDLER, Raymond. The Notebooks of Raymond Chandler and English Summer. A Gothic Romance. New York: The Ecco Press, 1976.

CHRISTIE, Agatha. And Then There Were Nonce. 1939. New York: Harper, 2011.

COELLO GUTIÉRREZ, Emiliano. "La pista de hielo (1993) en el contexto de la nueva novela negra latinoamericana”. Mitologías hoy 7, 2013, p. 75-83.

DÍAZ ETEROVIC, Ramón. La ciudad está triste. Santiago de Chile: LOM, 2000.

EPPLE, Juan Armando. "Leonado Padura Fuentes”. Hispamérica 71, 1995, p. 49-66.

FRANKEN KURZEN, Clemens A. Crimen y verdad en la novela policial chilena actual. Santiago de Chile: University of Santiago de Chile, 2013.

GARCÍA TALAVÁN, Paula. "La novela neopolicial latinoamericana: una revuelta ético-estética del género”. Cuadernos Americanos, v. 148, n.2, 2014, p. 63-85.

GARCÍA TALAVÁN, Paula. "Transgenericidad y cultura del desencanto: el neopolicial Ibero-Americano”. Letral 7, 2011, p. 49-58.

GIARDINELLI, Mempo. El género negro. City of Mexico: Autonomous Metropolitan University, 1996.

GIARDINELLI, Mempo. Qué solos se quedan los muertos. Barcelona: Plaza y Janés, 1986.

GOPEGUI, Belén. El padre de Blancanieves. Barcelona: Anagrama, 2007.

HERNÁNDEZ, Sonia and Puig, Marta. "Conclusión: una entrevista inédita. Entrañable huraño”. In: Paz Soldán, Edmundo y Faverón Patriau, Gustavo (eds.): Bolaño salvaje. Candaya: Barcelona, 2008, p. 475-478.

HERRALDE, Jorge. Para Roberto Bolaño. Medellin: Villegas Editores, 2007.

LOBO, Tatiana. El corazón del silencio. San Jose: Norma, 2004.

MARTÍN ESCRIBÁ, Álex and SÁNCHEZ ZAPATERO, Javier. "Una mirada al neopolicial latinoamericano: Mempo Giardinelli, Leonardo Padura y Paco Ignacio Taibo II". Anales de Literatura Hispanoamericana 36, 2007: 49-58.

MORA, Carmen de. "En torno a Los detectives salvajes". América sin nombre 16, 2001: 171-180.

NICHOLS, William J. "A quemarropa con Manuel Vázquez Montalván y Paco Ignacio Taibo II”. Arizona Journal of Hispanic Cultural Studies 2, 1998: 197-232.

NOGUEROL JIMÉNEZ, Francisca. "Neopolicial latinoamericano: el triunfo del asesino". Ciberletras. Revista de critica literaria y de cultura 15, 2006.

PADURA FUENTES, Leonardo. "Modernidad y posmodernidad: la novela policial en Iberoamérica”. Hispamérica 84, 1999, p. 37-50. 
PELLICER, Rosa. "Críticos detectives y críticos asesinos: la busca del manuscrito en la novela policíaca hispanoamericana (1990-2006)". Anales de Literatura Hispanoamericana 36, 2007, p. 19-35.

PINO, Miriam. "Roberto Bolaño y las reelecturas de la novela negra: La pista de hielo”. Literatura y lingüistica 1, Santiago de Chile, 2006: 117-128.

PINTO, Rodrigo. "La pista de hielo". In: Manzoni, Celia (ed.): Roberto Bolaño. La escritura como tauromaquia. Buenos Aires: Corregidor, 2002, p. 133-143.

PLIMPTON, George. "Ernest Hemingway. The art of fiction no. 21". The Paris Review 18, 1958. http://www.theparisreview.org/interviews/4825/the-art-offiction-no-21-ernest-hemingway. Accessed on 06/02/14.

REY ROSA, Rodrigo. Que me maten si. Barcelona: Seix Barral, 1997.

ROSSO, Ezequiel de. "Una lectura conjetural. Roberto Bolaño y el relato policial”. In: Manzoni, Celia (ed.). Roberto Bolaño. La escritura como tauromaquia. Buenos Aires: Corregidor, 2002. p. 133-143.

SÁNCHEZ VELASCO, Irene. El neopolicial chileno de las últimas décadas: teoría y práctica de un género narrativo. Doctoral dissertation. Madrid: Autonomous University of Madrid, 2010.

STOLZMANN, Uwe. “Entrevista a Roberto Bolaño”. In: López Bernasocchi, Augusta and López de Abiada, José Manuel (eds.). Roberto Bolaño. Estrella cercana. Ensayos sobre su obra. Madrid: Verbum, 2012, p. 364-376.

TAIBO II, Pacio Ignacio. Todo Belascoarán. La serie completa de Héctor Belascoarán Shayne. México D.F.: Planeta, 2010.

TAIBO II, Pacio Ignacio. La vida misma, City of Mexico: Planeta, 1987.

TRELLES PAZ, Diego. "Novela policial alternativa hispanoamericana (1960-2005)”. Aisthesis 40, 2006, p. 79-91.

VARAS, Patricia. "Belascoarán y Heredia: detectives postcoloniales". Ciberletras 15, 2006. http://www.lehman.cuny.edu/ciberletras/v15/varas.html. Accessed on $04 / 19 / 2017$. 
Julia González Calderón. É licenciada em Filologia Hispânica e mestre em Estudos Hispânicos pela Universidade de Sevilla. Atualmente cursa o Doutorado em Línguas e Literaturas Hispânicas na Universidade de Califórnia Los Angeles (UCLA). Sua pesquisa gira em torno da narrativa centro-americana contemporânea, a narrativa (neo)policial e os estudos de gênero. Tem trabalhado como professora de espanhol na Universidade de Michigan em Ann Arbor e tem desfrutado dum período de investigação na Universidade de Costa Rica com uma bolsa de pesquisa Santander em 2017.

E-mail: juliagon@ucla.edu 